\title{
Growth and Yield Response of Sugarcane Varieties to Wider Spacing
}

\author{
Firdoz Shahana*, B. Joseph, U. Nagabhushanam and B. Madhavi \\ Regional Sugarcane and Rice Research Station, Professor Jayashankar Telangana State \\ Agricultural University, Rudrur, Nizamabad, Telangana State, India \\ *Corresponding author
}

\section{Keywords}

Growth, Yield,

Sugarcane,

Wider Spacing

Article Info

Accepted:

17 April 2019

Available Online:

10 May 2019
A B S T R A C T

Currently sugarcane crop yields are low and its area under cultivation is declining due to its high cost of cultivation and continuous reduction in announcing less remunerative prices to the farmers by the policy makers. Of late the area under this crop is continuously declining in Telangana state of India. In order to facilitate the farmers to get lucrative prices and to increase area under this crop, sugarcane yields have to be enhanced more than $250 \mathrm{t} / \mathrm{ha}$. The routine practices of growing sugarcane in this area is with the row spacing of $90 \mathrm{~cm}$ with end to end overlapping three budded setts, But seed cane requirement and overall cost of cultivation with this practice is very high, which became a major cause for declining cultivation area under this crop. Hence, it is necessary to decrease the seed cane requirement by enhancing the spacing to $150 \mathrm{~cm} \mathrm{X} 60 \mathrm{~cm}$ distance. On the other hand planting of two single budded setts from selected healthy canes, (weighing not less than 50 grams) at each hill was found to be more effective in terms of higher tiller production and better utilization of nutrients and light due to wider spacing between rows besides decreasing seed rate to three-fourth of its original 3 budded setts.

\section{Introduction}

Currently sugarcane crop yields are low and its area under cultivation is declining due to its high cost of cultivation and continuous reduction in announcing less remunerative prices to the farmers by the policy makers. Of late the area under this crop is continuously declining in Telangana state of India. In order to facilitate the farmers to get lucrative prices and to increase area under this crop, sugarcane yields have to be enhanced more than $250 \mathrm{t} / \mathrm{ha}$. The routine practices of growing sugarcane in this area is with the row spacing of $90 \mathrm{~cm}$ with end to end overlapping three budded setts, But seed cane requirement and overall cost of cultivation with this practice is very high, which became a major cause for declining cultivation area under this crop.

Hence, it is necessary to decrease the seed cane requirement by enhancing the spacing to $150 \mathrm{~cm} \mathrm{X} 60 \mathrm{~cm}$ distance. On the other hand planting of two single budded setts from selected healthy canes, (weighing not less than 50 grams) at each hill was found to be more effective in terms of higher tiller 
production and better utilization of nutrients and light due to wider spacing between rows besides decreasing seed rate to three-fourth of its original 3 budded setts.

The main objectives of this study to evaluate popular varieties $85 \mathrm{R} 186$ and Co 86032 and pre released varieties $97 \mathrm{R} 129$ and $97 \mathrm{R} 401$ under wider spacing for decreased planting density and cost of cultivation. And also to minimize the cost of cultivation of the crop and increase the sugarcane yield.

\section{Materials and Methods}

A field experiment was conducted during 2013-14 and 2014-15 during winter season at Regional Sugarcane and Rice Research Station, Rudrur, Nizamabad, Telangana state, India, to study the growth and yield response of four sugarcane varieties $97 \mathrm{R} 129,97 \mathrm{R}$ 401, Co 86032 and 85 R 186 at wider spacing of $150 \mathrm{~cm}$ between rows and $60 \mathrm{~cm}$ within rows, using single budded sets as against 3 budded sets with row spacing of $90 \mathrm{~cm}$ and no definite spacing within the row. Experiment was laid out in Randomised Block design with five replications. Varieties were considered as treatments.

\section{Results and Discussion}

\section{Cane length, cane girth and single cane} weight

During the I year of study cane length did not differed between varieties but during II year of study cane length was significantly superior in varieties 97R401 (2.58m)and 85R186 (2.48m). Similar trend was observed from the two years mean data. Lal (1998) found that plant height increases with increase in row spacing. More plant height at wider spacing may be due to proper orientation and establishment of plants.

Cane girth and single cane weight also followed similar trend. The mean values for two years indicated that 97R 401 recorded significantly highest cane girth and single cane weight of $3.18 \mathrm{~cm}$ and $2.28 \mathrm{~kg}$ respectively it was followed by $85 \mathrm{R} 186$ with cane girth of $2.77 \mathrm{~cm}$ and single cane weight of $1.94 \mathrm{~kg}$.

Number of millable canes, cane yield and sugar yield

Two years mean data revealed significant differences between varieties for number of millable canes (NMC), cane yield and finally sugar yield. The important yield attributing parameter NMC which contributes $70 \%$ towards cane yield was significantly higher in variety Co-86032 (76.1 t/ha), followed by 97 R 401 (68.15 t/ha).

Similar results were reported by Cheema et $a l ., 2002$. Cane yield was significantly higher in $97 \mathrm{R} 401$ variety (152 t/ha). It may be mainly attributed to higher number of millable canes and more height \& single cane weight recorded with this variety.

The presence of significant incident sunlight contributed to higher photo assimilate production and better partioning of dry matter contributed to higher cane yield in wider spacing. Other varieties 85R186 \& Co 86032 recorded on par cane yields of $123 \mathrm{t} / \mathrm{ha} \& 118$ t/ha respectively. Though significantly higher NMC was recorded in Co 86032 due to less cane girth and single cane weight cane yield was less in this variety.

These results were in confirmation with Nazir, 2000; Mahadevaswamy and Martin, 2002. But on the other hand commercial cane sugar\% (CCS\%) was significantly higher in Co 86032 hence sugar yield which is a function of cane yield was also significantly higher in Co 86032 (16 t/ha). It was followed by $85 \mathrm{R} 186$ (15 t/ha) (Table 1 and 2). 
Table.1 Yield attributing parameters of sugarcane varieties planted at wider spacing

\begin{tabular}{|c|c|c|c|c|c|c|c|c|c|}
\hline \multirow{2}{*}{$\begin{array}{c}\text { Name of the } \\
\text { variety }\end{array}$} & \multicolumn{3}{|c|}{ Cane length (m) } & \multicolumn{3}{|c|}{ Cane girth (cm) } & \multicolumn{3}{|c|}{ Single cane weight $(\mathbf{k g})$} \\
\hline & 2013-14 & 2014-15 & $\begin{array}{c}\text { Mean of } 2 \\
\text { years }\end{array}$ & 2013-14 & 2014-15 & $\begin{array}{c}\text { Mean of } 2 \\
\text { years }\end{array}$ & 2013-14 & 2014-15 & $\begin{array}{c}\text { Mean of } 2 \\
\text { years }\end{array}$ \\
\hline 97 R 401 & 2.346 & 2.578 & 2.60 & 3.214 & 3.146 & 3.18 & 2.326 & 2.234 & 2.28 \\
\hline 97 R 129 & 2.436 & 2.224 & 2.33 & 2.792 & 2.708 & 2.75 & 1.882 & 1.872 & 1.87 \\
\hline Co 86032 & 2.146 & 2.216 & 2.18 & 2.392 & 2.324 & 2.33 & 1.69 & 1.552 & 1.56 \\
\hline 85 R 186 & 2.644 & 2.48 & 2.56 & 2.726 & 2.814 & 2.77 & 1.99 & 1.896 & 1.94 \\
\hline $\mathrm{CD}(\mathrm{P}=0.05)$ & NS & 0.28 & 0.27 & NS & 0.52 & 0.43 & 0.237 & 0.26 & 0.20 \\
\hline
\end{tabular}

Table.2 Cane yield and sugar yield of Sugarcane varieties planted at wider spacing

\begin{tabular}{|c|c|c|c|c|c|c|c|c|c|c|c|c|}
\hline \multirow{2}{*}{$\begin{array}{c}\text { Name of the } \\
\text { variety }\end{array}$} & \multicolumn{3}{|c|}{ NMC(000/ha) } & \multicolumn{3}{|c|}{ Cane yield(t/ha) } & \multicolumn{3}{|c|}{ CCS\% } & \multicolumn{3}{|c|}{ Sugar yield(t/ha) } \\
\hline & 2013-14 & 2014-15 & $\begin{array}{c}\text { Mean of } \\
2 \text { years }\end{array}$ & 2013-14 & 2014-15 & $\begin{array}{l}\text { Mean of } \\
2 \text { years }\end{array}$ & 2013-14 & 2014-15 & $\begin{array}{c}\text { Mean of } \\
2 \text { years }\end{array}$ & 2013-14 & 2014-15 & $\begin{array}{l}\text { Mean of } \\
2 \text { years }\end{array}$ \\
\hline 97 R 401 & 59.00 & 77 & 68 & 123.90 & 149 & 152 & 9.67 & 8.93 & 9.30 & 16.30 & 13.33 & 14 \\
\hline 97 R 129 & 45.10 & 74 & 59.5 & 91.55 & 126 & 109 & 12.84 & 12.74 & 12.79 & 11.75 & 16.05 & 14 \\
\hline Co 86032 & 71.20 & 81 & 76 & 121.04 & 115 & 118 & 13.57 & 13.33 & 13.45 & 16.42 & 15.32 & 16 \\
\hline 85 R 186 & 59.30 & 69 & 64 & 155.36 & 123 & 123 & 13.16 & 11.48 & 12.32 & 15.02 & 14.12 & 15 \\
\hline $\mathrm{CD}(\mathrm{P}=\mathbf{0 . 0 5})$ & 8.089 & 8.06 & 4.67 & 3.83 & 14.67 & 8.21 & 1.18 & 1.07 & 1.02 & 0.64 & 1.52 & 1.07 \\
\hline
\end{tabular}


From the above field study, it can be concluded that varieties co 86032, 85R186, 97R401 are suitable for cultivation in wider spacing in terms of higher cane and sugar yield. These varieties can be recommended for cultivation with wider spacing in Telangana state. Further, using single budded setts at $60 \mathrm{~cm}$ intrarow spacing has enhanced yield which may be attributed to lesser competition between stalks for nutrients and light leading to development of healthy and heavy canes resulting in decreasing mortality rate of these canes, facilitating towards more cane yield, compared to high density planting which results in higher cane population with weak and thinner light weight stalks (Rao, 1990). Furthermore, high density planting reduces the number of tillers produced per each planting material due to mutual shading and competition for light, nutrients, and water (Verma, 2004). This study also indicated that sugarcane has the capacity to compensate for population densities. Furthermore there is possibility of reducing seed cost requirement to 1 ton /ha against traditional 4 tons /ha due to usage of two single budded setts per each hill, over three budded setts placed end to end overlapping within the furrow, thus reducing the overall cost of cultivation. Further wide row planting also facilitates mechanization and possibility of raising suitable intercrops booning additional income which may attract the farming community to prefer sugarcane crop to other crops which are being cultivated in this state.

\section{References}

Cheema, I.A., Ayub M. and Abdul Jabbar. 2002. Morphological response of spring planted sugarcane. Cooperative Sugarcane, 6(3): 94-95.

Lal, B. 1988. Yield quality and root distribution of sugarcane co 1148 as influenced by method of planting. Bharatia Sugar. 14(1): 59-60.

Mahadevaswamy, M.G.T and Martin. 2002. Production potential for wide row sugarcane inter-cropped with aggregatum onion. Indian Journal of Agronomy. 2002. 47(3): 366.

Rao, P.N. 1990. Recent Advance in Sugarcane. M/S the K.C.P. Limited, Vuyyuru-India.

Verma, R.S. 2004. Sugarcane Projection Technology in India. International Book Distributing Co. Lucknow. India.

\section{How to cite this article:}

Firdoz Shahana, B. Joseph, U. Nagabhushanam and Madhavi, B. 2019. Growth and Yield Response of Sugarcane Varieties to Wider Spacing. Int.J.Curr.Microbiol.App.Sci. 8(05): 20782081. doi: https://doi.org/10.20546/ijcmas.2019.805.242 